\title{
Morphology of the DIN 100Cr6 Case Hardened Steel after Plasma Nitrocarburizing Process
}

\author{
Marcos Alves Fontes ${ }^{a}$, Vladimir Henrique Baggio Scheid ${ }^{b}$, David de Souza Machadoc,
}

\section{Luiz Carlos Casteletti ${ }^{d}$ Pedro Augusto de Paula Nascente ${ }^{e}$}

\author{
${ }^{a}$ Instituto Federal de Educação, Ciência e Tecnologia de São Paulo, Sertãozinho, SP, Brasil \\ ${ }^{b}$ Instituto de Estudos Avançados, Departamento de Ciência e Tecnologia Aeroespacial, São José dos \\ Campos, SP, Brasil \\ ${ }^{c}$ Tecumseh do Brasil, Tecumseh Products Company, São Carlos, SP, Brasil \\ ${ }^{d}$ Departamento de Engenharia de Materiais, Universidade de São Paulo, São Carlos, SP, Brasil \\ ${ }^{e}$ Departamento de Engenharia de Materiais, Universidade Federal de São Carlos, São Carlos, SP, \\ Brasil
}

Received: September 11, 2018; Revised: February 14, 2019; Accepted: March 09, 2019

\begin{abstract}
Nitrocarburizing is considered one of the most important thermochemical treatments for surface modification of metallic materials and involves the simultaneous diffusion of nitrogen and carbon onto the surface. Understanding and controlling the formation of the nitrocarburized layer have considerable industrial interest due to the improvements regarding wear, fatigue, and corrosion resistances. DIN $100 \mathrm{Cr} 6$ steel samples were treated by plasma nitrocarburizing for two hours, with two treatment temperatures $\left(550\right.$ and $\left.600^{\circ} \mathrm{C}\right)$ and four methane concentrations in the gas mixture composition $(0$, $1.0,1.5$, and $2.0 \%$ ). SEM and XRD analyses, and wear resistance tests were used to characterize the samples. Results showed that the treatment temperature and atmosphere composition had considerable influence on the compound layer morphology. For nitrided samples the compound layer consists of $\gamma^{\prime}-\mathrm{Fe}_{4} \mathrm{~N}$ phase, and the presence of carbon in the gas mixture helps stabilize the $\varepsilon-\mathrm{Fe}_{2-3} \mathrm{~N}$ phase. Higher $\mathrm{CH}_{4}$ concentration in the treatment atmosphere improve the sample superficial wear resistance.
\end{abstract}

Keywords: Surface modification, plasma nitrocarburizing, wear resistance.

\section{Introduction}

The plasma nitrocarburizing is a thermochemical process of surface hardening that uses a glow discharge to introduce nitrogen and carbon simultaneously onto the material surfaces ${ }^{1,2}$. This process is usually recommended for carbon steels, as they do not have enough constituents to form nitrides such as other medium alloy steels ${ }^{3}$. The process modifies the alloy surface proprieties due to the formation of crystalline phases such as iron nitrides and/or carbonitrides ${ }^{4}$, improving considerably the corrosion ${ }^{5}$ and wear resistances ${ }^{6-12}$. Recently there have been a number of reports dealing with the nitrocarburizing of steels ${ }^{6,7,13-15}$.

The nitrocarburizing process can be carried out at temperatures above or below the temperature of the transformation of the $\alpha$ phase (ferrite) to the $\gamma$ phase (austenite) of Fe-N diagram (temperature of $590^{\circ} \mathrm{C}$ ). The process is termed ferritic nitrocarburizing if it occurs bellow the eutectoid temperature, and a compound layer is formed over a diffusion zone enriched in nitrogen. If the process occurs above the eutectoid temperature, it is termed austenitic nitrocarburizing, and there is a partial transformation of the ferritic matrix into the austenite phase, with the formation of three layers: the compound layer, the diffusion zone, and between these two layers, the so called transformed austenite layer. This austenite layer can transform into martensite during rapid cooling of the sample, thereby increasing the hardness in the region below the compound layer ${ }^{1}$.

The most desirable phase to comprise the microstructure of the compound layer is the single $\varepsilon-\mathrm{Fe}_{2-3} \mathrm{~N}$ phase. However, it has been found that the compound layer formed by plasma nitrocarburizing usually consists of a heterogeneous mixture of $\varepsilon-\mathrm{Fe}_{2-3} \mathrm{~N}$ and $\gamma^{\prime}-\mathrm{Fe}_{4} \mathrm{~N}$ phases ${ }^{16,17-19}$.

The compound layer composition is quite sensitive to the chemical composition of the treatment atmosphere. According to the Fe-C-N phase diagram, the presence of carbon in the gas mixture contributes to the formation of the $\varepsilon-\mathrm{Fe}_{2-3} \mathrm{~N}$ phase ${ }^{20,21}$. A plasma nitriding without carbon in its treatment atmosphere is able to produce a microstructure in the compound layer composed by only the $\gamma^{\prime}-\mathrm{Fe}_{4} \mathrm{~N}$ phase ${ }^{22,23}$, with the formation of no $\varepsilon-\mathrm{Fe}_{2-3} \mathrm{~N}$ phase, or only a small amount of it ${ }^{24}$. The stabilization of the $\varepsilon-\mathrm{Fe}_{2-3} \mathrm{~N}$ phase is possible by using, for instance, methane as a carbon source in the nitrocarburizing atmosphere ${ }^{25,26}$.

The high solubility of nitrogen on the steel, leads to the high nitrogen level in the near surface and greatly contributes to the penetration of carbon atoms towards the substrate, as if the carbon atoms are pushed into the lower part of the hardened layer by the nitrogen atoms, resulting in a low carbon level in the N-enriched layer. ${ }^{27}$. 
The purpose of this study is to investigate the influence of the temperature and the methane concentration on the wear resistance and microstructure of DIN 100Cr6 steel submitted to the plasma nitrocarburizing process.

\section{Experimental Procedure}

The DIN 100Cr6 steel substrates, with chemical composition presented in Table 1, were plasma nitrocarburized by a pulsed d.c. glow discharge under a pressure of $300 \mathrm{~Pa}$, using a MP250 industrial equipment. The applied current and voltage (range of 300 to $500 \mathrm{~V}$ ) were controlled to achieve and assure the desirable processes temperatures.

The following conditions were used as parameters: two different treatment temperatures, $550 \pm 5^{\circ} \mathrm{C}$ and $600 \pm 5^{\circ} \mathrm{C}$; nitrocarburizing treatment time fixed in 2 hours; and atmospheres with $74 \% \mathrm{~N}_{2}$ and concentrations of $1,1.5$, and $2.0 \%$ of $\mathrm{CH}_{4}$, with $\mathrm{H}_{2}$ as balance. A single steel substrate was nitrided under an atmosphere of $25 \% \mathrm{H}_{2}-75 \% \mathrm{~N}_{2}$. The samples were slow cooled in the plasma chamber using an inert atmosphere. The Table 2 summarizes the experimental data for the nitrocarburizing process.

XRD analyses were performed using a Rigaku X-ray Equipment, model Geiger-Flex, under the following conditions: $\mathrm{Cu}-\mathrm{K} \alpha$ radiation $(\lambda=1.54056 \AA)$, scan angle $(\theta-2 \theta)$ from $5^{\circ}$ to $90^{\circ}$, advance angle: $0.032^{\circ}$ second. The Diffrac EVA software was used for spectral analysis.

SEM analyses were performed using a Philips XL30 FEG microscope equipped with an energy dispersive spectrometer (EDS).

For the tribological analysis, it was employed a ball-on-disk test, with a $25,4 \mathrm{~mm}$ diameter and hardened chromium-steel ball material. A load of $1.21 \mathrm{~N}$, speed of $400 \mathrm{rpm}$, without lubricants or abrasives, and test times of 5, 10, 15, and 20

Table 1. Chemical composition of the samples.

\begin{tabular}{cccc}
\hline \multicolumn{4}{c}{ Chemical composition (wt.\%) } \\
\hline $\mathbf{C}$ & $\mathbf{C r}$ & $\mathbf{M n}$ & $\mathbf{S i}$ \\
$0.98-1.10$ & $1.30-1.60$ & $0.25-0.45$ & $0.15-0.35$ \\
\hline
\end{tabular}

minutes were the parameters used in the tests (the test time is proportional to the sliding distance, so the results show the sliding distance variable instead of test time). The wear parameters were chosen to produce a wear crater diameter proportional to the sample size, and this way, to compare the values between the different tests times chosen.

The wear crater diameters were measured using a Carl Zeiss reflective light microscope, model Axio Lab.A1, with integrated camera. The wear volumes and the wear crater depth of the samples were calculated according to Eq. (1), given in $\mathrm{mm}^{3}{ }^{28}$, and Eq. (2), given in $\mathrm{mm}^{29}$ respectively.

$$
V=\frac{\pi \cdot b^{4}}{64 . r}
$$

Where $r$ represents the radius of the sphere [mm], $b$ is the wear crater diameter $[\mathrm{mm}], V$ is the wear volume $\left[\mathrm{mm}^{3}\right]$.

$$
V=\frac{\pi}{3} \cdot h^{2} \cdot(3 \cdot R-h)
$$

Where $r$ is the radius of the sphere [mm], $h$ is the crater depth [mm], and $V$ is the wear volume $\left[\mathrm{mm}^{3}\right]$.

\section{Results and Discussion}

Figs. 1 and 2 display the XRD diffractograms for the hardened layers produced at $550^{\circ} \mathrm{C}$ and $600^{\circ} \mathrm{C}$ respectively, under four different $\mathrm{CH}_{4}$ concentrations in the gas mixture.

The nitrided sample presents intense peaks associated to the $\gamma^{\prime}-\mathrm{Fe}_{4} \mathrm{~N}$ phase and only very minor peaks of the $\varepsilon-\mathrm{Fe}_{2-3} \mathrm{~N}$ phase, as reported by Nobuki et al. ${ }^{30}$. The compound layers formed under higher amount of $\mathrm{CH}_{4}$ consists mainly of the $\varepsilon-\mathrm{Fe}_{2-3} \mathrm{~N}$ phase with trace amounts of the $\gamma^{\prime}-\mathrm{Fe}_{4} \mathrm{~N}$ phase. The addition of methane in the gas mixture increased the amount of carbon in the nitrocarburized atmosphere, and consequently increased the $\varepsilon-\mathrm{Fe}_{2-3} \mathrm{~N}$ phase amount in the modified surface layer, as reported in the literature ${ }^{22,23,26}$.

The nitrogen and carbon mean concentration profiles of the nitrocarburized layer produced on DIN $100 \mathrm{Cr} 6$ steel at $550^{\circ} \mathrm{C}$ and $600^{\circ} \mathrm{C}$ are shown in Figs. 3 and 4, respectively. It can be observed that a dual-layer structure was produced,

\begin{tabular}{|c|c|c|c|c|c|c|c|}
\hline \multirow{3}{*}{ Condition } & \multicolumn{7}{|c|}{ Experimental data } \\
\hline & \multirow{2}{*}{ Pressure (Pa) } & \multirow{2}{*}{ Voltage (V) } & \multirow{2}{*}{ Time (h) } & \multirow{2}{*}{$\begin{array}{c}\text { Temperature } \\
\left({ }^{\circ} \mathrm{C}\right)\end{array}$} & \multicolumn{3}{|c|}{ Gas Mixture (Concentration in $\mathrm{cm}^{3} / \mathrm{min}$ ) } \\
\hline & & & & & $\mathrm{CH}_{4}$ & $\mathrm{~N}_{2}$ & $\mathrm{H}_{2}$ \\
\hline 1 & \multirow{8}{*}{300} & \multirow{8}{*}{300 to 500} & & \multirow{4}{*}{$550 \pm 5$} & $0 \%$ & $75 \%$ & $25 \%$ \\
\hline 2 & & & & & $1 \%$ & $74 \%$ & \\
\hline 3 & & & & & $1.5 \%$ & $74 \%$ & Balance \\
\hline 4 & & & & & $2 \%$ & $74 \%$ & \\
\hline 5 & & & 2 & \multirow{4}{*}{$600 \pm 5$} & $0 \%$ & $75 \%$ & $25 \%$ \\
\hline 6 & & & & & $1 \%$ & $74 \%$ & \\
\hline 7 & & & & & $1.5 \%$ & $74 \%$ & Balance \\
\hline 8 & & & & & $2 \%$ & $74 \%$ & \\
\hline
\end{tabular}

Table 2. Experimental data for the nitrocarburizing process. 


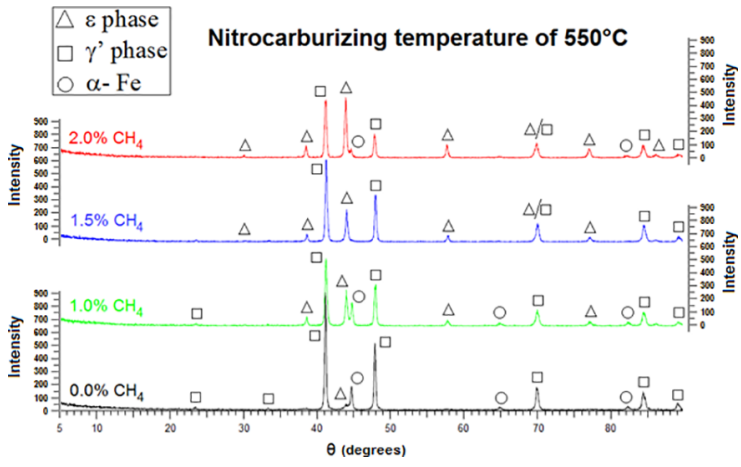

Figure 1. XRD diffractograms for samples treated at $550^{\circ} \mathrm{C}$.

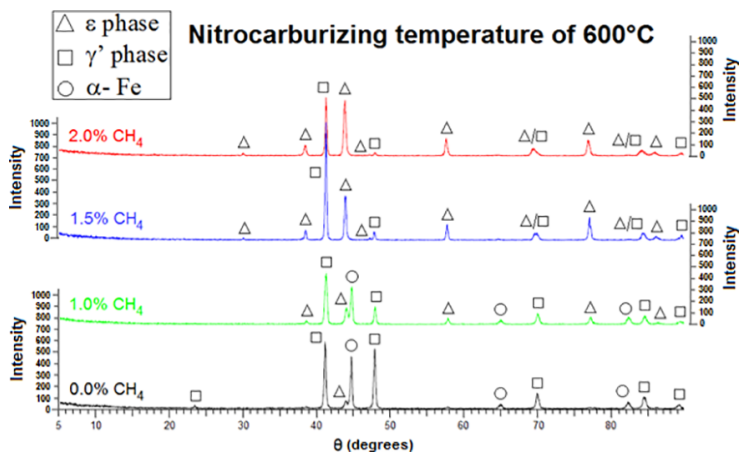

Figure 2. XRD diffractograms for samples treated at $600^{\circ} \mathrm{C}$.

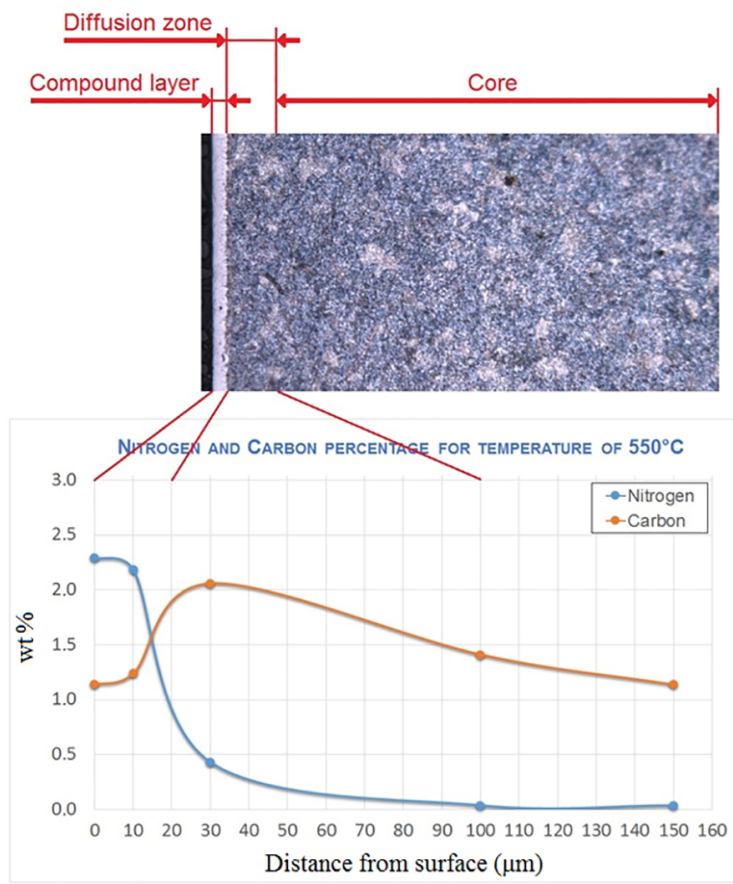

Figure 3. Chemical composition profiles for the samples nitrocarburized at $550^{\circ} \mathrm{C}$.

comprising of a N-enriched layer with a high nitrogen content on top of a C-enriched layer with a high carbon content ${ }^{6,14}$. This is explained by the presence of the $\varepsilon-\mathrm{Fe}_{3} \mathrm{~N}$ and $\gamma^{\prime}-\mathrm{Fe}_{4} \mathrm{~N}$ phases found in the compound layer for all

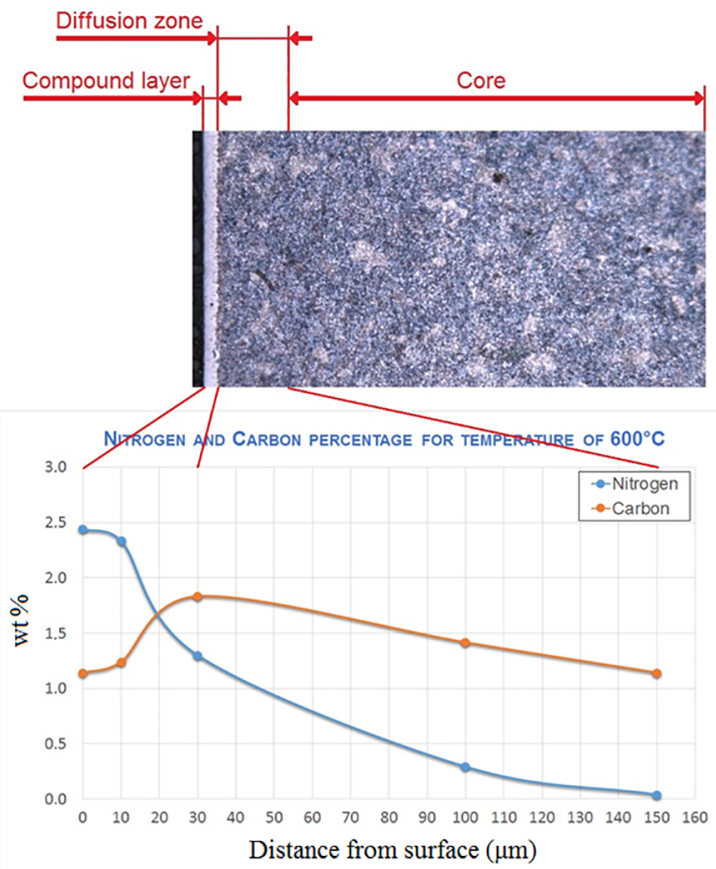

Figure 4. Chemical composition profiles for the samples nitrocarburized at $600^{\circ} \mathrm{C}$.

nitrocarburized samples treated at both temperatures ${ }^{18,31,32}$. The low amount of carbon in the compound layer is a consequence of the high nitrogen concentration, due to the higher thermodynamic stability of the nitrides in relation to the carbides ${ }^{33}$. The high solubility of nitrogen leads to the high nitrogen level in the near surface region and greatly contributes to the penetration of carbon atoms towards the interior of the steel ${ }^{27}$. This can be pictured as follows: the carbon atoms are pushed into the lower part of the hardened layer by the nitrogen atoms, resulting in a low carbon level in the N-enriched layer.

It is possible to observe the presence of a small amount of nitrogen and a large amount of carbon in the diffusion zone, but both amounts decrease along the chemical composition line until they reach the chemical composition of the sample core ${ }^{14}$.

The compound layer morphology for almost all samples is illustrated in Fig 5. In the upper part of the compound layer, which contains the porous layer, the predominant phase is the $\varepsilon$ phase. In the lower part of the compound layer, which presents a columnar pattern structure, $\varepsilon$ and $\gamma^{\prime}$ are the predominant phases ${ }^{33,34}$.

Figs. 6 and 7 show the images of the wear craters obtained after the fixed ball wear test for the eight nitrocarburized samples under the eight different treatment conditions at $550^{\circ} \mathrm{C}$ and $600^{\circ} \mathrm{C}$, respectively.

Each row in Figs. 6 and 7 are associated to the wear crater images of the nitrocarburized samples at different $\mathrm{CH}_{4}$ concentrations, where the first row shows the results with $0 \% \mathrm{CH}_{4}$ concentration, the second with $1 \%$, the third 


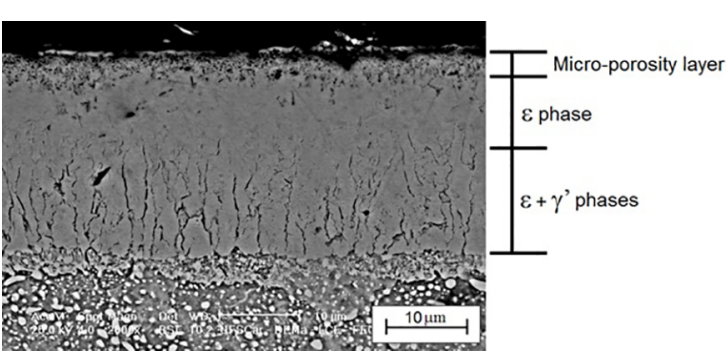

Figure 5. SEM micrograph of the surface modified layer for a nitrocarburized sample, showing the micro-porosity layer on top and the presence of $\varepsilon$ and $\gamma^{\prime}$ phases.

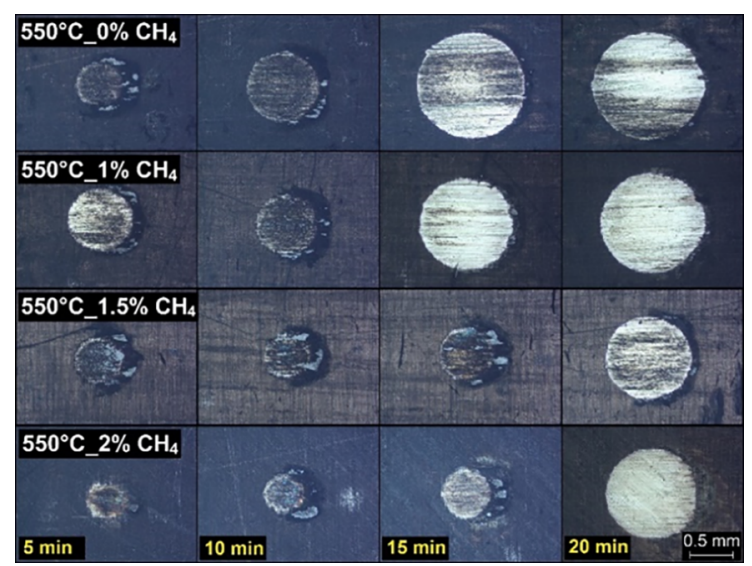

Figure 6. Wear craters for the samples nitrocarburized at $550^{\circ} \mathrm{C}$.

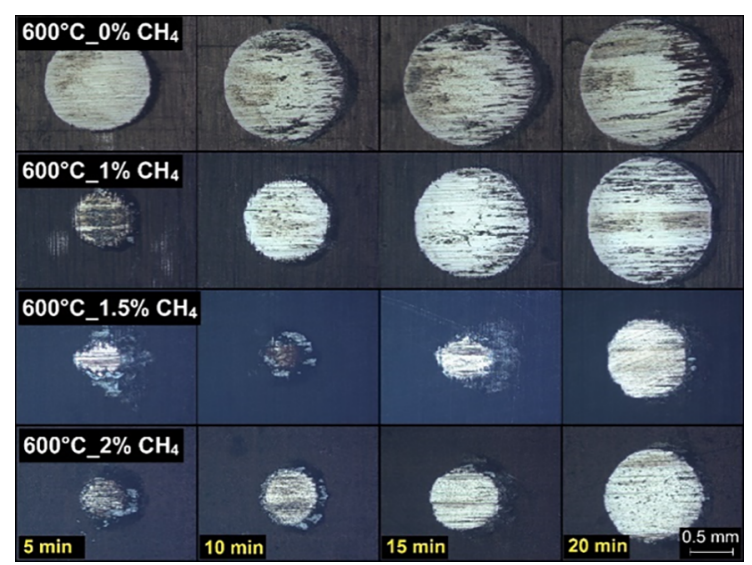

Figure 7. Wear craters for the samples nitrocarburized at $600^{\circ} \mathrm{C}$.

$1.5 \%$, and the fourth row with $2 \%$. The columns represent the wear crater images for the four different test times. The first column for the test time of 5 minutes (or sliding distance of $160 \mathrm{~m}$ ), the second column, for 10 minutes (sliding distance of $320 \mathrm{~m}$ ), the third, for 15 minutes (sliding distance of $480 \mathrm{~m}$ ), and the fourth, for 20 minutes (sliding distance of $640 \mathrm{~m}$ ).

From Figs. 6 and 7, it is possible to verify that the wear mechanism presented in all nitrocarburized samples is the abrasive wear. The damaged zone for all samples, presented scratches and groove appearance caused by the removal of material from the surface.
Once the values of the wear crater diameters were determined, the Eq. (1) was used to calculate the wear volume, and the results are presented in Figs. 8 and 9, for $550^{\circ} \mathrm{C}$ and $600^{\circ} \mathrm{C}$ respectively.

The results show that the nitrocarburized samples with richer $\mathrm{CH}_{4}$ concentrations, regardless of the process temperature, present the best wear resistances. These results can be attributed to the distinct phases formed in the compound layer for different nitrocarburizing parameters. The higher wear resistance values are associated to the samples that were nitrocarburized with $1.5 \%$ and $2 \%$ of $\mathrm{CH}_{4}$, at both temperatures, and the reason for this, is the presence, in the microstructures of the modified layers, of a large quantity of the $\varepsilon-\mathrm{Fe}_{2-3} \mathrm{~N}$ phase with only traces of the $\gamma^{\prime}-\mathrm{Fe}_{4} \mathrm{~N}$ phase. The high concentration of methane in the gas mixture promotes the formation of the $\varepsilon-\mathrm{Fe}_{2-3} \mathrm{~N}$ phase, which has a higher hardness and a higher wear resistance than the $\gamma^{\prime}-\mathrm{Fe}_{4} \mathrm{~N}$ phase ${ }^{35}$.

The wear crater depth was calculated using Eq. (2). For all nitrocarburizing samples, the wear craters depth were not enough to exceed the superficial layer produced, as shown in Figs. 10 and 11 , for $550^{\circ} \mathrm{C}$ and $600^{\circ} \mathrm{C}$ respectively.

For samples nitrocarburized with 1.5 and $2 \%$ of $\mathrm{CH}_{4}$, the presence of $\varepsilon$ phase with high thickness, was essential to provide low material removal at wear testing, and consequently, reduction of wear crater depth.

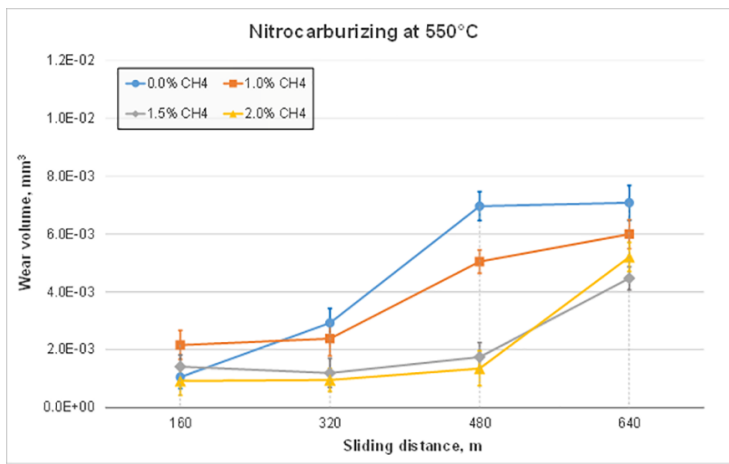

Figure 8. Wear volume for the samples nitrocarburized at $550^{\circ} \mathrm{C}$ as a function of methane concentration and the sliding distance.

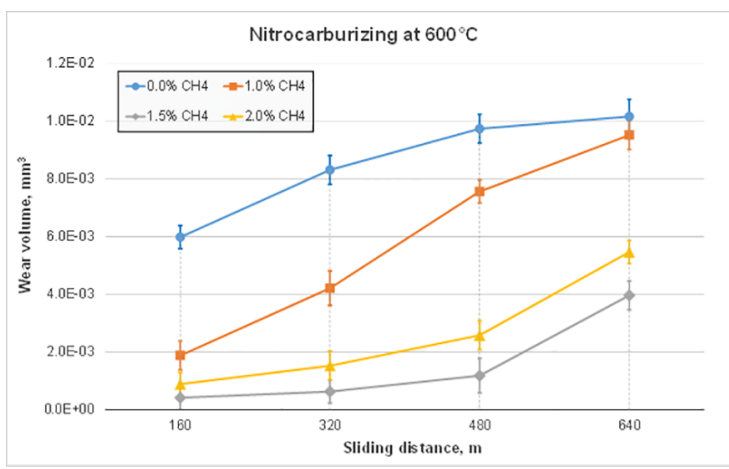

Figure 9. Wear volume for the samples nitrocarburized at $600^{\circ} \mathrm{C}$ as a function of methane concentration and the sliding distance. 


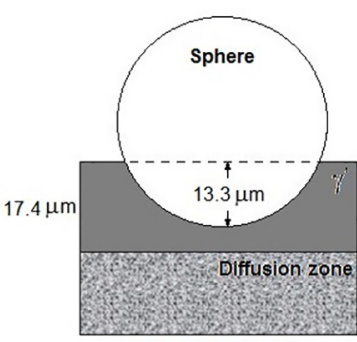

$550^{\circ} \mathrm{C} ; 0 \% \mathrm{CH}_{4} ; 20 \mathrm{~min}$

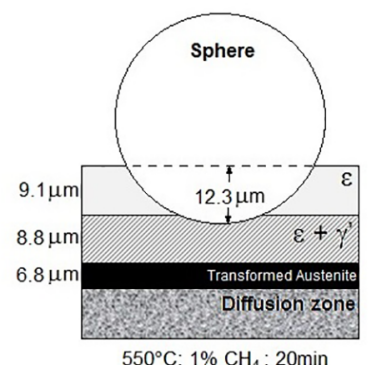

$550^{\circ} \mathrm{C} ; 1 \% \mathrm{CH}_{4} ; 20 \mathrm{~min}$

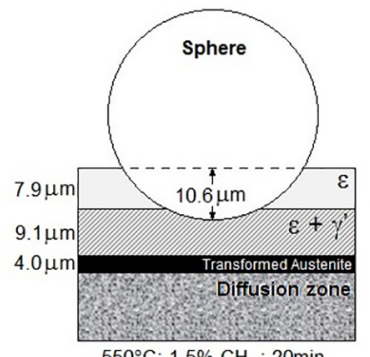

$550^{\circ} \mathrm{C} ; 1.5 \% \mathrm{CH}_{4} ; 20 \mathrm{~min}$

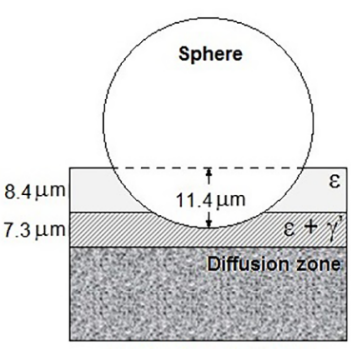

$550^{\circ} \mathrm{C} ; 2 \% \mathrm{CH}_{4} ; 20 \mathrm{~min}$

Figure 10. Schematic illustration of wear crater depth (temperature of $550^{\circ} \mathrm{C}$ and 20 minutes testing).

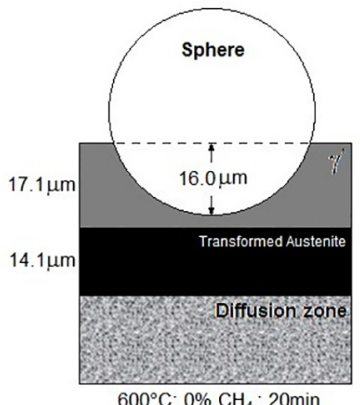

$600^{\circ} \mathrm{C} ; 0 \% \mathrm{CH}_{4} ; 20 \mathrm{~min}$

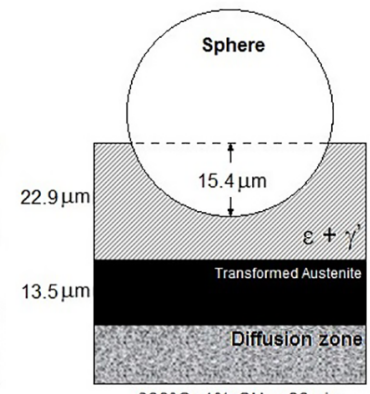

$600^{\circ} \mathrm{C} ; 1 \% \mathrm{CH}_{4} ; 20 \mathrm{~min}$

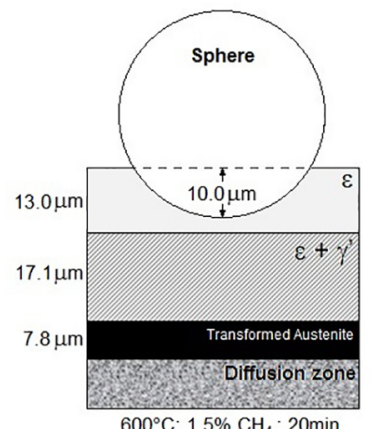

$600^{\circ} \mathrm{C} ; 1.5 \% \mathrm{CH}_{4} ; 20 \mathrm{~min}$

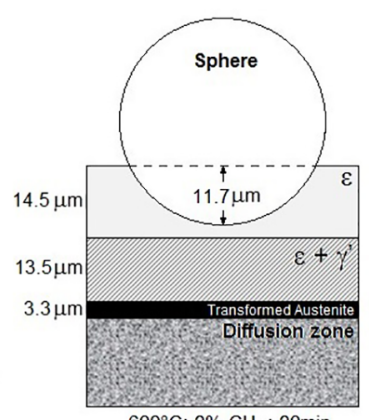

$600^{\circ} \mathrm{C} ; 2 \% \mathrm{CH}_{4} ; 20 \mathrm{~min}$

Figure 11. Schematic illustration of wear crater depth (temperature of $600^{\circ} \mathrm{C}$ and 20 minutes testing).

\section{Conclusions}

From the present study of the microstructure and tribological behavior of plasma nitrocarburized DIN $100 \mathrm{Cr} 6$ steel, the following can be concluded:

- The parameters studied in this thermochemical treatment, such as temperature and chemical composition of the gas mixture, affect the surface layer tribological properties and morphology.

- The nitrided samples have a compound layer which was composed only by the $\gamma^{\prime}-\mathrm{Fe}_{4} \mathrm{~N}$ phase. For the nitrocarburized samples, the compound layer is a mixture of $\varepsilon-\mathrm{Fe}_{2-3} \mathrm{~N}$ and $\gamma^{\prime}-\mathrm{Fe}_{4} \mathrm{~N}$ phases.

- The amount of each one of these phases is a function of the $\mathrm{CH}_{4}$ concentration present in the nitrocarburizing atmosphere.

- The lowest wear rate was achieved for the samples that had been nitrocarburized using a gas mixture richer in $\mathrm{CH}_{4}$, regardless of the process temperature.

- The wear mechanism presented in all nitrocarburized samples is the abrasive wear.

\section{Acknowledgements}

This work was supported by CNPq (processes 30455/2013-4 and 302450/2017-2) and FAPESP (process 2017/25983-8). The XRD analyses were carried out at the Structural Characterization Laboratory of the Department of Materials Engineering of the Federal University of Sao Carlos (LCE/DEMa/UFSCar).

\section{References}

1. Mittemeijer EJ, Somers MAJ, eds. Thermochemical Surface Engineering of Steels. Cambridge: Woodhead Publishing; 2015.

2. Brink BK, Ståhl K, Christiansen TL, Somers MAJ. The ternary Fe-C-N system: homogeneous distributions of nitrogen and carbon. Journal of Alloys and Compounds. 2017;690:431-437.

3. Brühl SP, Cabo A, Tuckart W, Prieto G. Tribological behaviour of nitrided and nitrocarburized carbon steel used to produce engine parts. Industrial Lubrication and Tribology. 2016;68(1):125133.

4. Jack KH. Results of further X-ray structural investigations of the iron-carbon and iron-nitrogen systems and of related interstitial alloys. Acta Crystallographica. 1950;3(5):392-394.

5. Barua A, Kim H, Lee I. Effect of the amount of $\mathrm{CH}_{4}$ gas on the characteristics of surface layers of low temperature plasma nitrided martensitic precipitation-hardening stainless steel. Surface and Coatings Technology. 2016;307(Pt B):1034-1040.

6. Alphonsa J, Raja VS, Mukherjee S. Development of highly hard and corrosion resistant A286 stainless steel through plasma nitrocarburizing process. Surface and Coatings Technology. 2015;280:268-276.

7. Anjos AD, Scheuer CJ, Brunatto SF, Cardoso RP. Low-temperature plasma nitrocarburizing of the AISI 420 martensitic stainless steel: Microstructure and process kinetics. Surface and Coatings Technology. 2015;275:51-57. 
8. Yuya M, Sano N, Tahira H, Egashira M, Nishitani S. Effect of Pre-heat Treatment on Hardening Behavior in Gas Nitrocarburized Carbon Steel. ISIJ International. 2016;56(7):1241-1247.

9. Boztepe E, Alves AC, Ariza E, Rocha LA, Cansever N, Toptan F. A comparative investigation of the corrosion and tribocorrosion behaviour of nitrocarburized, gas nitrided, fluidized-bed nitrided, and plasma nitrided plastic mould steel. Surface and Coatings Technology. 2018;334:116-123.

10. Nikolova M, Nikolov D, Derin B, Yankov E. Effect of vacuum oxy-nitrocarburizing on the microstructure of tool steels: an experimental and modeling study. MATEC Web of Conferences. 2017;94:03011.

11. Takeya G, Mariani F, Casteletti L, Lombardi A, Totten G. Aging of a Fe-Mn-Al Steel Using Plasma Nitrocarburizing. Materials Performance and Characterization. 2017;6(4):554-560.

12. Singh G, Brar G. Modification of EN9 steel surface by salt bath nitrocarburizing process. Journal of Materials Science \& Surface Engineering. 2017;5(4):577-580.

13. Vales SS, Becerra EAO, Brito PP, Droppa Junior R, Garcia JL, Alvarez F, et al. Effect of low temperature nitriding of $100 \mathrm{Cr} 6$ substrates on TiN coatings deposited by IBAD. Materials Research. 2015;18(1):54-58.

14. Wu D, Ge Y, Kahn H, Ernst F, Heuer AH. Diffusion profiles after nitrocarburizing austenitic stainless steel. Surface and Coatings Technology. 2015;279:180-185.

15. Lee I, Barua A. Behavior of the S-phase of plasma nitrocarburized 316L austenitic stainless steel on changing pulse frequency and discharge voltage at fixed pulse-off time. Surface and Coatings Technology. 2016;307(Pt B):1045-1052.

16. Sohi MH, Ebrahimi M, Raouf AH, Mahboubi F. Effect of plasma nitrocarburizing temperature on the wear behavior of AISI 4140 steel. Surface and Coatings Technology. 2010;205(Suppl 1):S84-S89.

17. Wang YX, Yan MF, Li B, Guo LX, Zhang CS, Zhang YX, et al. Surface properties of low alloy steel treated by plasma nitrocarburizing prior to laser quenching process. Optics \& Laser Technology. 2015;67:57-64.

18. Sola R, Poli G, Veronesi P, Giovanardi R. Effects of Surface Morphology on the Wear and Corrosion Resistance of Post-Treated Nitrided and Nitrocarburized 42CrMo4 steel. Metallurgical and Materials Transactions A. 2014;45(6):2827-2833.

19. Zhou Z, Dai M, Shen Z, Hu J. A novel rapid D.C. salt bath nitrocarburizing technology. Vacuum. 2014;109:144-147.

20. Basso RLO, Figueroa CA, Zagonel LF, Pastore HO, Wisnivesky D, Alvarez F. Effect of Carbon on the Compound Layer Properties of AISI H13 Tool Steel in Pulsed Plasma Nitrocarburizing. Plasma Processes and Polymers. 2007;4(Suppl 1):S728-S731.

21. Dalke A, Burlacov I, Spies HJ, Biermann H. Use of a solid carbon precursor for DC plasma nitrocarburizing of AISI 4140 steel. Vacuum. 2018;149:146-149.
22. Lu S, Miao B, Song L, Song R, Wei K, Hu J. Enhancement of wear resistance of AISI 1045 steel by a two-step plasma treatment. Vacuum. 2017;145:153-157.

23. Ye X, Wu J, Zhu Y, Hu J. A study of the effect of propane addition on plasma nitrocarburizing for AISI 1045 steel. Vacuum. 2014;110:74-77.

24. Rie KT, Schnatbaum F. Influence of pulsed d.c.-glow-discharge on the phase constitution of nitride layers during plasma nitrocarburizing of sintered materials. Materials Science and Engineering: A. 1991;140:448-453.

25. Davis JR, ed. Surface Hardening of Steels: Understanding the Basics. Materials Park: ASM International; 2002.

26. Silva HRT, Egert P, Seeber A, Speller C. Effect of Methane Addition on Formation of Plasma Nitrocarburized Layers. Metallography, Microstructure, and Analysis. 2016;5(6):486492.

27. Lee I. Effect of processing temperatures on characteristics of surface layers of low temperature plasma nitrocarburized AISI $204 \mathrm{Cu}$ austenitic stainless steel. Transactions of Nonferrous Metals Society of China. 2012;22(Suppl 3):s678-s682.

28. Rutherford KL, Hutchings IM. A micro-abrasive wear test, with particular application to coated systems. Surface and Coatings Technology. 1996;79(1-3):231-239.

29. Kassman Å, Jacobson S, Erickson L, Hedenqvist P, Olsson M. A new test method for the intrinsic abrasion resistance of thin coatings. Surface and Coatings Technology. 1991;50(1):7584.

30. Nobuki T, Hatate M, Kawasaki Y, Ikuta A, Hamasaka N. Effects of Nitriding and Nitro-carburizing on the Fatigue Properties of Ductile Cast Iron. International Journal of Metalcasting. 2017;11(1):52-60.

31. Zhang CS, Yan MF, Sun Z, Wang YX, You Y, Bai B, et al. Optimizing the mechanical properties of M50NiL steel by plasma nitrocarburizing. Applied Surface Science. 2014;315:2835 .

32. Miao B, Chai Y, Wei K, Hu J. A novel duplex plasma treatment combining plasma nitrocarburizing and plasma nitriding. Vacuum. 2016;133:54-57.

33. Mittemeijer EJ. Fundamentals of Nitriding and Nitrocarburizing. In: Dossett J, Totten GE, eds. ASM Handbook, Volume 4A: Steel Heat Treating Fundamentals and Processes. Materials Park: ASM International; 2013.

34. Fattah M, Mahboubi F. Microstructure Characterization and Corrosion Properties of Nitrocarburized AISI 4140 Low Alloy Steel. Journal of Materials Engineering and Performance. 2012;21(4):548-552.

35. Wei R, Shogrin B, Wilbur PJ, Ozturk O, Williamson DL, Ivanov I, et al. The Effects of Low-Energy-Nitrogen-Ion Implantation on the Tribological and Microstructural Characteristics of AISI 304 stainless steel. Journal of Tribology. 1994;116(4):870-876. 